\title{
Conceptualising Ideational Convergence of China and OECD Donors: Coalition Magnets in Development Cooperation
}

\author{
Heiner Janus and Tang Lixia
}

\subsection{INTRODUCTION}

China's continued economic growth and increasing level of engagement on the international stage have spurred an intense debate over China's role as a rising power in development cooperation. Academic literature has painted a nuanced picture of Chinese foreign aid, such as defining (Bräutigam 2011; Grimm et al. 2011; Li 2012), tracking (Kitano and Harada 2016), and assessing the allocation and effects of Chinese foreign aid (Strange et al. 2017). One dominating theme across this literature is a focus on the differences between Chinese and Organisation for Economic Co-operation and Development (OECD) development cooperation and the development cooperation of members of the OECD. ${ }^{1}$ For instance, China does not define and assess its aid according to the OECD-Development Assistance Committee's (DAC) definition of official development assistance (ODA) but reports aid based on own standards (Bräutigam 2011).

China is usually portrayed as a challenger to the DAC donors and an alternative model (Hackenesch 2013; Kragelund 2015; Woods 2008; Zhang

H. Janus $(\varangle)$

German Development Institute / Deutsches Institut für Entwicklungspolitik (DIE), Bonn, Germany

e-mail: heiner.janus@die-gdi.de

L. Tang

China Institute for South-South Cooperation in Agriculture,

China Agricultural University, Beijing, China

e-mail: tanglx@cau.edu.cn

(C) The Author(s) 2021

S. Chaturvedi et al. (eds.), The Palgrave Handbook of Development

Cooperation for Achieving the 2030 Agenda,

https://doi.org/10.1007/978-3-030-57938-8_10 
et al. 2015). Debates on Chinese development cooperation also tend to be embedded in comparisons between DAC donors and "emerging donors" such as Brazil, India, South Africa, and China (Chin and Quadir 2012; Li and Carey 2014; Rowlands 2012). This literature assesses whether OECD-DAC and non-DAC donors such as China converge or diverge in terms of rhetoric, motives, norms (Reilly 2012), conditionality, thematic focus, institutional structures (Sidiropoulos et al. 2015), and modalities (Vazquez et al. 2016). Typically, these studies focus on explaining the differences between Chinese and OECD-DAC aid and often conclude that they are largely irreconcilable.

Despite long-standing differences between China and OECD donors, however, there has been a growing overlap between the aid activities of China and DAC donors across several areas of cooperation in recent years. On the one hand, OECD donors have increasingly pursued their national interests in development cooperation (Gulrajani 2017; Mawdsley 2017b). On the other hand, China has initiated a big push on global development. Most notably, China has launched the Belt and Road Initiative (BRI), also known as "the Silk Road of the 21 st Century", massively increasing investments and its profile across Asia and Africa (Chun 2017). In addition, China has stepped up its engagement in multilateralism. During its G20 presidency in 2018, China championed the implementation of the 2030 Agenda for Sustainable Development, linking G20 and United Nations (UN) activities. Two new multilateral institutions-the New Development Bank ("BRICS [Brazil, Russia, India, China and South Africa] bank") and the Asian Infrastructure Investment Bank-are backed by China. Based on these observations of China's increased level of international engagement and the related literature on Chinese foreign aid, this chapter analyses potential areas of convergence between China and other international actors.

As a deliberate choice and in contrast to other academic literature, this analysis does not emphasise the differences between China and OECD-DAC donors but focuses on the concept of "ideational convergence" (Bickerton et al. 2015; Radaelli 2006). Ideational convergence is defined as the extent to which ideas held by different development actors become more similar over time. There are three main reasons for this approach. First, there is a gap in unpacking convergence in the literature, as most research focuses on the differences between China and other actors. In particular, there is an increasing level of convergence of ideas between China and OECD-DAC donors regarding international development that current political theories do not fully explain. Second, even within broad areas of convergence, there are nuanced differences that this analysis reveals. Third, for normative reasons, we believe that an increased understanding of convergence is needed to foster cooperation among different global development actors.

In addition, the analysis focuses on the international development discourse $^{2}$ and the importance of ideas for determining political outcomes, following a constructivist approach to international relations. This chapter emphasises the role of discourse, capturing both ideas and the interactive process by which ideas are conveyed, because discourse can help to explain 
how specific policies and initiatives are adopted and why political change occurs (Schmidt 2008). When viewing international development as a policy field, ideas are crucial for coordinated action by helping to organise coalitions around the shared goals and identities of different actors (Fligstein and McAdam 2012; Yanguas 2017). Although the "turn to ideas" (Jessop 2001; Schmidt 2008) has been ongoing in the political science literature, few of these ideational theories have been applied to study Chinese foreign engagement (Feng 2016; Wang and Blyth 2013).

For China as a development actor, a focus on ideas fits well because ideas formulated by the country's leadership are the cornerstone of its policymaking, including Chinese foreign aid. At the same time, policy-making in China is often characterised as a gradual, experimental, and adaptive process (Ang 2016; Qian 2017). Therefore, it is investigated whether the meaning of ideas and their interpretations change over time, especially in the Chinese policy discourse on foreign aid (Varrall 2013; Zhang et al. 2015). The key research question for this chapter is: How can the convergence of ideas in international development cooperation be conceptualised, and which specific ideas indicate a convergence on development thinking between China and OECD donors?

This analysis is structured in four parts. First, the theoretical background on ideas and institutions for explaining Chinese foreign aid is introduced. Next, the concept of "coalition magnets" is defined and the analytical framework is laid out. Third, three coalition magnets are identified: mutual benefit, development results, and the 2030 Agenda. For each of these coalition magnets, the potential of fostering joint OECD-DAC and Chinese engagement in development cooperation is explored. The final part contextualises the findings in the current development discourse and presents conclusions.

The chapter relies mainly on desk research with a focus on the academic and policy literature from OECD countries and China as well as interviews conducted in China with foreign aid experts from September to October 2017. Moreover, a wide range of official and unofficial sources was consulted to understand how development cooperation discourse is expressed, particularly in contemporary Chinese elite discourse. Official documents and grey literature allow for examining how Chinese elites interpret and elaborate on official Chinese government narratives, and how they seek to portray such narratives to domestic and foreign audiences.

\subsection{ThEORETICAL BACKGROUND: UNDERSTANDING China's Rise Through Ideas and Institutions}

Chinese foreign policy has changed radically in recent years. In the 1990s, President Deng Xiaoping had characterised China's foreign policy strategy as "taoguang yanghui, yousuo zuowei" (keeping a low profile while trying to accomplish something) because of the radical shifts in the international order after the collapse of the Soviet Union (Lee 2016; Wang 2014). The United 
States had become the global superpower, and China did not want to challenge them, and neither took on a leadership role in the "Global South". In the past two decades, Presidents Jiang Zemin and Hu Jintao followed this policy of maintaining a low profile in international relations and mainly concentrated on China's economic growth (Lee 2016). With President Xi Jinping, however, the world has witnessed a massive expansion of Chinese engagement abroad. Contrary to his predecessors, President Xi uses terms such as "China Path" or "China Dream" (Sørensen 2015) to suggest "a strong nation capable of global leadership and of representing an alternative model of governance that sets China apart from market-led capitalism or liberal democracy" (Shi-Kupfer et al. 2017, p. 9).

International relations theories analysing the increase in China's international efforts, including foreign aid, usually focus on national interest as the main driver. Typically, pursuing national interest within an anarchic system of sovereign nation states means increasing state power relative to other states, either through hard or "soft power" (Ding 2010; Nye 2004). Cooperation between China and other actors in this context is viewed as being driven purely by the pursuit of material self-interest and eventually leading to conflict (Allison 2017; Gilpin 1983; Mearsheimer 2010). However, these theories are insufficient to fully explain the rapid expansion of - and the changes inChinese development cooperation. For instance, soft power has limitations, both as a deliberate Chinese political strategy and as an analytical lens. Soft power is often used as an empty catch-all term with little analytical precision, neglecting the nuances of international engagement (Rawnsley 2016). Besides, soft power requires a specific context - typically a common rule-governed institutional setting and the presence of underlying mutual interest-in order to be utilised effectively as an explanatory factor (Kearn 2008). China's communication of its foreign policy, however, still targets a domestic audience and does not resonate abroad, leading to limited success of its soft power strategies (Gill and Huang 2006; Lee 2016; Shambaugh 2015).

Furthermore, Chinese efforts to protect global public goods such as the Paris Agreement, the Iran nuclear deal, or the global free trade regime cannot be solely explained as a strategy to expand power at the expense of other countries. Ideas of enlightened self-interest or global cooperation could provide a complementary explanation that has yet to be studied in greater detail (Anand 2004; Kaul et al. 1999; Kenny et al. 2018). Thus, applying an ideational framework to assess the power of ideas to form coalitions of political actors may help to explain the increased level of Chinese engagement in foreign aid. Another important argument for an ideational approach to studying China's foreign engagement is the role of ideas in its policy-making. As an authoritarian one-party state, ideas and discourses in China are key factors in determining political outcomes. Those presenting ideas in the Chinese academic literature often react to changes in the official policies of the Chinese Communist Party, which determines what "correct ideas" are (Chin et al. 2013). 
Scholars have thus far not applied discursive frameworks widely in studying the Chinese domestic discourse. Rationalist international relations frameworks tend to view China as a monolithic actor, without unpacking domestic policy discourse. Our analysis builds on "discursive institutionalism" (Schmidt 2008, 2010), which is complementary to the new institutionalist approaches of historical institutionalism, rational choice institutionalism, and sociological institutionalism. A major criticism against these three institutionalisms is that institutions have become overly deterministic, and agents have mostly set preferences or are fixated by norms. Hay argues that

actors as driven either by utility maximization in an institutionalized game scenario (rational choice institutionalism) or by institutionalized norms and cultural conventions (normative/sociological institutionalism) or, indeed, both (historical institutionalism), are unlikely to offer much analytical purchase on questions of complex post-formative institutional change. (Hay 2006a, p. 6)

Discursive institutionalism moves away from this static perspective of viewing institutions as largely constraining rules that are external to the actors. Instead, discursive institutionalism defines institutions as being simultaneously given (the context within which agents think, speak, and act) as well as contingent (as the results of agents' thoughts, words, and actions) (Schmidt 2008, p. 314). Hence, institutions are internal to the actors and serve both as structures that constrain behaviour and as constructs created and changed by those actors (Schmidt 2008, p. 314). Actors then engage through ideas and discourse with these institutions to maintain or change institutional outcomes or policies (Béland 2005). For the Chinese context, this discursive institutionalist approach offers a complementary perspective to the dominant rational choice heavy literature and explains how Chinese political behaviour and policy-making outcomes are driven by ideas rather than solely by self-interest (Campbell 2002).

Ideas themselves are increasingly crucial for understanding processes of political change. We define ideas as causal beliefs about economic, social, and political phenomena (Béland and Cox 2016). Ideas are cognitive products, meaning that they are interpretations of the material world in the mind, and ideas posit relationships (formal and informal) between things and events, and they are guides (causes) for actions (Béland and Cox 2010, pp. 3-4). Institutions are understood as "carriers of ideas" or "collective memories", following Schmidt (2011). Power ${ }^{3}$ is understood as the ability to shape outcomes and reach particular goals (Béland and Cox 2016; Morriss 2006), which includes the dimension of ideational power (Carstensen and Schmidt 2016). Power is a key factor in this process of discourse when actors promote certain ideas at the expense of other ideas. Ideas and power can interact in various ways, for example through discourse. 
For the analysis, the focus is placed on ideas that can serve as vehicles for collective action and coalition-building, and the role of policy entrepreneurs to use framing processes to influence discourse. Policy entrepreneurs are broadly defined as "people who are willing to invest resources of various kinds in hopes of a future return in the form of policies they favour" (Kingdon 1984, p. 143). These policy entrepreneurs could be political leaders, elected officials, party members, policy-makers, the media, interest groups, public intellectuals, opinion-makers, social movements, or ordinary people. Policy entrepreneurs use strategic framing, a process by which actors use their ideas and their power to influence discourse (Béland and Cox 2016, p. 432).

\subsection{Analytical Framework: IDEAS AS COALITION MAgnets}

We adopt an ideational framework developed by Béland and Cox (2016), who argue that ideas can shape political power relations through their role as "coalition magnets", defined as the capacity of an idea to appeal to a diverse set of individuals and groups, and to be used strategically by policy entrepreneurs.

Béland and Cox (2016) highlight two critical characteristics of an idea that makes it attractive for policy entrepreneurs to employ as a coalition magnet. First, ambiguous and polysemic ideas that appeal to a range of heterogeneous actors for different reasons have a strong potential for becoming coalition magnets. The broader the idea, the easier it is for policy entrepreneurs to bring different constituencies together and transcend political divisions. Clearly defined and narrow ideas are typically less suited. Second, ideas need to be valent, meaning that they evoke emotional reactions that can be positive or negative and have low or high intensity. Particularly, ideas with a positive and high-intensity valence are likely to have strong coalition-building potential.

Once policy entrepreneurs determine to use a specific idea as a coalition magnet, they typically seek to create a new language that is unfamiliar to actors in a given policy debate, or they use existing language in a new and unfamiliar way. Next, key actors in the policy debate with decision-making authority need to embrace the idea and grant legitimacy to the given policy preference. Finally, different actors whose perceived interests had previously placed them at odds need to engage jointly with the particular issue in new ways, or actors that had previously not been engaged in a given issue need to do so. When these circumstances are in place, Béland and Cox (2016) argue that an idea can become a coalition magnet that policy entrepreneurs use to alter power relations and political outcomes. As an example of coalition magnet ideas, they analyse the ideas "sustainability", "solidarity", and "social inclusion". 
The main limitations of the coalition magnet framework are similar to limitations of discursive institutionalism or constructivist ideational theories. Primarily, there is a risk that ideational theories ascribe a vague or almost meaningless role to institutions (Bell 2011), or what Hay (2006b) calls "ideational voluntarism". In particular, ideational theories need to address the structureagency problem and determine the relationship between the ideational and the material. A series of methodological issues follow from this ontological challenge, as any ideational theory needs to clarify the relation between institutions, ideas, and policy outcomes. For the specific case of coalition magnet ideas, it is crucial to understand them as "ideas empowering actors" (Parsons 2016), whereby the challenge for the analysis is to track who champions the ideas, how their agendas relate to perceived problems, how these change over time, and to what extent actors have shared core understandings or different interpretations of a given idea.

The framework is applied to three ideas in international development cooperation-mutual benefit, development results, and the 2030 Agenda - to assess their potential as coalition magnets (Table 10.1). In the analysis, the ambiguity and valence of the idea are assessed first, and then the analysis shifts to which actors embrace the idea to grant it legitimacy, before turning to the question of whether policy entrepreneurs are already using the idea as a coalition magnet. The analysis does not, however, go beyond the analysing stage of agenda-setting in the policy process because the main focus lies on assessing the strengths and weaknesses of each policy idea with respect to fostering convergence between China and OECD-DAC development actors. However, coalitions may be fragile after the agenda-setting stage, especially

Table 10.1 Potential coalition magnet ideas in development cooperation

\begin{tabular}{|c|c|c|c|}
\hline Idea & Mutual benefit & Development results & 2030 Agenda \\
\hline $\begin{array}{l}\text { Articulation of } \\
\text { idea }\end{array}$ & $\begin{array}{l}\text { Principle of South-South } \\
\text { cooperation and Chinese } \\
\text { aid }\end{array}$ & $\begin{array}{l}\text { Principle of } \\
\text { OECD-DAC } \\
\text { development } \\
\text { cooperation }\end{array}$ & $\begin{array}{l}\text { United Nations } \\
\text { Development } \\
\text { Agenda }\end{array}$ \\
\hline $\begin{array}{l}\text { Policy proposals } \\
\text { (examples) }\end{array}$ & $\begin{array}{l}\text { Chinese white papers on } \\
\text { foreign aid }\end{array}$ & $\begin{array}{l}\text { OECD-DAC managing } \\
\text { for development results, } \\
\text { results-based } \\
\text { management }\end{array}$ & $\begin{array}{l}\text { National plans for } \\
\text { achieving } \\
\text { Sustainable } \\
\text { Development Goals } \\
\text { (SDGs) }\end{array}$ \\
\hline Scale of coalition & $\begin{array}{l}\text { Mainly providers of } \\
\text { South-South cooperation, } \\
\text { increasingly popular } \\
\text { among OECD-DAC } \\
\text { donors }\end{array}$ & $\begin{array}{l}\text { Mainly OECD-DAC } \\
\text { donors, increasingly } \\
\text { popular among } \\
\text { South-South } \\
\text { cooperation providers, } \\
\text { including China }\end{array}$ & $\begin{array}{l}\text { All international } \\
\text { development actors }\end{array}$ \\
\hline
\end{tabular}

Source Authors, based on Béland and Cox (2016) 
regarding implementation or other post-agenda-setting stages of the policy cycle (Howlett et al. 2009). Ultimately, coalition magnets can also become "empty signifiers" (Laclau 1996), ideas that bring disparate people together in a common cause but otherwise have no attachment to precise content. Still, coalition magnet ideas are not assumed to "float freely" but are anchored in transnational policy networks and different domestic structures that differ in terms of state-society relations as well as values and norms embedded in political cultures (Risse-Kappen 1994). This analysis, therefore, contextualises its findings against the background of global development discussions and domestic challenges that policy entrepreneurs face by analysing different types of discourse that link ideas with collective action (Schmidt 2011).

Three ideas are purposefully selected to cover different domains of aid policy-making (motives, implementation, goal system) and different associations in terms of actors that are predominantly linked to the specific idea. The first idea, mutual benefit, is being discussed in the context of the underlying motives of development cooperation and has been a cornerstone of Chinese foreign aid and South-South cooperation. For this idea, we also analyse to what extent OECD-DAC countries have used it. The second idea represents the implementation and management side of foreign aid, namely what is often termed "development results" - the idea that aid interventions should lead to measurable improvements in people's lives. This idea has been codified by OEDC-DAC donors in various policy documents, whereas China has only gradually moved into this direction. The third idea represents the goal system of international development, namely the 2030 Agenda, which was agreed in the UN in 2015 and theoretically applies to all development actors equally, including those from China and OECD-DAC countries.

\subsection{Three Potential Coalition Magnets}

\subsubsection{Mutual Benefit}

The idea of "mutual benefit", or "mutual interest" (Li et al. 2014), has a long history in development cooperation and is anchored in South-South cooperation and Chinese foreign aid. In the Bandung Conference of African and Asian states in 1955, participants endorsed five principles of peaceful coexistenceincluding the principle of equality and mutual benefit-which has its roots in the Soviet aid model (Johnston and Rudyak 2017). In 1964, Chinese Premier Zhou Enlai laid out eight principles for "China's Aid to Third World Countries", which again included "equality and mutual benefit" as the first principle. Since then, mutual benefit has been reaffirmed in numerous Chinese policy documents, such as the Chinese white papers on foreign aid in 2011 (China State Council 2011) and 2014 (China State Council 2014).

Mutual benefit is a highly polysemic idea, since its meaning is interpreted differently by various actors. In a Chinese context, "mutual benefit" is often mentioned along with "win-win outcomes" and is used across all areas 
of Chinese engagement with other countries, including political, economic, cultural, and security relations (Chen 2017). In the foreign aid context, mutual benefit is understood as a mix of trade, investment, and aid. Moreover, in the South-South rhetoric, mutual benefit is portrayed as a counter-model to the OECD-DAC approach (Grimm 2014). Here, the mutual benefit expresses a partnership among equals (horizontal cooperation) and not the benevolent gifts of an altruistic donor to a recipient country (vertical cooperation). Still, the question of how benefits are distributed precisely between China and its partners is usually not specified when mutual benefit is mentioned in Chinese policy documents. Besides, power relations between China and its partners can be skewed and unbalanced, even when benefits are mutual (Grimm 2014; Hackenesch 2013).

In development discourse, mutual benefit traditionally has not been seen as particularly valent. DAC donors emphasise developing country benefits such as poverty reduction or access to better services. Yet, donor motivations for aid allocation decisions have always been driven by a mix of interests (Hulme 2016) and mostly dominated by political and economic interests (Alesina and Dollar 2000; Berthélemy 2006). But own national interests of donors are often presented in direct contradiction to altruistic (also called benevolent or humanitarian) donor motives. This notion is based on research that indicates aid is less likely to be effective when given for strategic reasons as opposed to being allocated for developmental purposes (Dreher et al. 2016; Minoiu and Reddy 2010). In addition, mutual benefit contradicts efforts of OECD-DAC donors to "untie aid", and the official ODA definition highlights that interests related to commercial endeavours and poverty reduction should be separated.

In recent years, there has been a strong trend towards a more open acknowledgement of national interests in the development discourse and practices of OECD-DAC donors (Gulrajani 2017; Keijzer and Lundsgaarde 2017; Mawdsley 2017b). As a consequence, the legitimacy of acknowledging mutual benefit is increasing. Some see this trend mostly as a "shift in discourse communicating the goals of development cooperation to domestic audiences" (Keijzer and Lundsgaarde 2017 , p. 7) and not a fundamental change. Since the financial crisis in 2009 , however, national interests, such as security, political, and economic interests, have taken a front seat in aid discourse. As part of a trend towards "retroliberalism" (Mawdsley et al. 2016; Murray and Overton 2016), donors such as the United Kingdom, Australia, New Zealand, Canada, and the Netherlands have strengthened the private sector and export orientation of their aid. Another trend has been the rising number of refugees and migrants coming to Europe, which triggered massive shifts in the allocation of aid budgets. In Germany's aid budget, the "in-donor refugee costs" have increased from about 1 per cent in 2014 to almost 17 per cent in 2015 (Knoll and Sheriff 2017, p. 17).

One driver of the mutual interest trend is the rise of emerging economies, which are challenging the traditional OECD model of aid. The "BRICS effect" (Younis 2013) has contributed to OECD donors reconsidering their 
approaches to aid. Collier (2016) even states that a focus on mutual benefit in aid is ethical, arguing that the aid partnership will be more genuine and stable than under a purely charitable approach. Previously, Collier described how "Western aid would adopt a model close to Chinese aid" (Collier 2013, p. 15) in terms of linking public investments with private enterprises.

For China, the question is to what extent the interpretation of mutual benefit has changed since the 1950s. First, policy ideas in China are often announced in rather vague terms from the leadership and then later interpreted and implemented by a large staff of civil servants in a process that has been termed "directed improvisation" (Ang 2016), suggesting potential space for experimentation. Second, the interpretation of "orthodox" norms can change over time. One example is the evolution of the "win-win" idea, which has gone through multiple "historic leaps" and rounds of "new thinking", whereby the original, more narrow meaning has expanded to all types of engagement between China and other countries (Chen 2017). Another example is the Chinese norm of "non-interference", whereby China has softened its stance and become increasingly interventionist in the field of peace and security (Grimm 2014). A similar process of softening seems to be taking place for the idea of mutual benefit, whereby the distribution of benefits is slowly tilting towards the partner countries. In the context of China's BRI, for example, China is investing in many high-risk projects and regions, where the immediate benefits predominantly fall to the partners.

A further indication of a shift in the interpretation of mutual benefit was the introduction of the term "community of shared future for mankind" by President $\mathrm{Xi}$ in 2015. This principle has quickly risen to become one of the most influential ideas in Chinese foreign policy. Yang Jiechi, a high-ranking foreign policy official, stated that "a new form of international relations characterized by mutual respect, fairness, justice, and mutual benefit is the basic path toward a community of shared future for humanity" (Yang 2018). Although scholars warn about a "sinocentric" (Callahan 2013; Nordin and Weissmann 2017) world view of the Chinese leadership when it speaks about a "community of shared destiny", there has been a noticeable shift of Chinese discourse towards "actively shouldering our international responsibilities and obligations" (Chen 2017). Such thinking echoes debates on "global public goods" (Ahluwalia et al. 2016; Cepparulo and Giuriato 2016), in which national interests, such as protecting the global climate, health, and security regimes, are put in the context of collective development challenges.

This analysis indicates that mutual benefit has the potential to be strategically used by policy entrepreneurs to foster convergence around this idea. The idea is polysemic, as it covers multiple dimensions of Chinese foreign engagement, including foreign aid, and is understood differently across China, other South-South cooperation providers, developing countries, and OECD-DAC donors. The valence of mutual benefit has further shifted from generating a high negative-intensity reaction among OECD-DAC donors towards greater acceptance and endorsement. Next, mutual benefit has been legitimised by 
China and OECD-DAC donors across different policy documents. Nevertheless, as of yet, policy entrepreneurs have not used mutual benefit as a coalition magnet to bring China, other South-South cooperation providers, developing countries, and OECD-DAC donors together. Discussions on common principles for foreign aid remain fragmented across different international platforms (Li et al. 2018; Mawdsley 2017a).

\subsubsection{Development Results}

The idea of development results entails the performance of foreign aid being continuously measured across multiple dimensions, including financial, economic, social, and environmental dimensions. Development results are firmly embedded in the OECD-DAC approach to foreign aid and date back to the 1960s, when "aid projects" (Baum and Tolbert 1985) were being implemented in increasingly formalised ways (e.g. through the introduction of the project cycle and project analysis). Later, in the 1980s, the "new public management" (Minogue et al. 1998) trend spread private-sector management approaches with the intent of making aid more market- and performanceorientated (Hood 1991; Turner et al. 2015). Today, the "results agenda" has firmly taken hold of many aspects of foreign aid (Eyben et al. 2015) - for instance as a principle for effective development cooperation-in the form of results frameworks for the management of aid organisations (Holzapfel 2016), results-based approaches for disbursing aid funds (Janus and Klingebiel 2014), and in the 2030 Agenda with its 17 goals and 169 indicators. In China, the Ministry of Commerce issued "Management Methods of Foreign Assistance Complete Projects" in 2009 and "Regulations on China's Foreign Aid Management" in 2014 (China Ministry of Commerce 2014) outlining an evaluation system of Chinese aid (Zhou 2016). In 2018, the Chinese government set up the China International Development Cooperation Agency to better manage its aid delivery (Zhou and Zhang 2018).

The development results idea in foreign aid can be polysemic because the critical question is: Whose results? Given a large number of aid stakeholders, such as donors, the donors' publics, recipient governments, and the recipient countries' publics, there can be diverging interests and power imbalances across the various relationships between these stakeholders. For instance, the drivers of the results trend among OECD-DAC countries are the interest to measure the effectiveness of foreign aid and the need to be accountable and report to aid constituents. In Chinese aid, too, the idea of development results can be polysemic, and results encompass those in the recipient countries as well as the results for China (Zhou 2016). Early mentions of results-such as Premier Zhou Enlai's eight principles of foreign aid in 1964 (Zhou 1964) which include "quick results", are different from more recent documents on Chinese foreign aid that mention "substantial results" (China State Council 2011), "win-win results" (China State Council 2014), and "real results" (Xi 2017). 
The idea of development results is typically seen as valent because achieving results is appealing to most stakeholders of foreign aid. However, the seemingly value-neutral results agenda among DAC donors can mask underlying political issues in administering aid, which has led to push back on the uncritical endorsement of the results agenda (Eyben et al. 2015; Paul 2015). DAC donors typically define results along a "results chain", in which only outcomes and impacts (improvements in people's lives) are viewed as results, and aid evaluations are made public to foster accountability. However, results frameworks that are used for reporting on foreign aid also include expenditures on administering aid, such as personnel costs for aid workers, and DAC donors have openly advocated integrating self-interest-oriented metrics into ODA reporting.

Still, the idea of development results enjoys high legitimacy, both in the DAC and in the Chinese context. The results agenda of DAC members and efforts to track the effectiveness of foreign aid and inform constituents remain high on the policy agenda. In political and formal terms, "managing for development results" is one of the five principles of the Paris Declaration on Aid Effectiveness (Organisation for Economic Co-operation and Development [OECD] 2005/2008). In South-South cooperation, which includes Chinese foreign aid, the Nairobi Outcome Document from 2009 and the 2019 outcome document of the High-level Conference on South-South Cooperation in Buenos Aires both affirm that the "impact of South-South cooperation should be assessed with a view to improving, as appropriate, its quality in a results-oriented manner" (United Nations General Assembly 2009, p. 4; 2019, p. 9).

A potential convergence around development results could, for instance, occur on a technical level of monitoring and evaluating foreign aid. Although the SDGs provide a potential guiding framework for reporting on development results, DAC donors aim to provide more nuanced information concerning results by differentiating results data in two main ways. First, they want to distinguish between three tiers: development results in the form of outcomes or impacts on the national and global levels, development cooperation results attributable to donors, and performance information on the organisations providing aid (OECD 2017; Zwart 2017). Second, DAC donors want to report disaggregated results information according to different purposes: accountability to constituents, communication for public relations, strategic direction, and learning for improving effectiveness. Yet, these discussions are ongoing, and balancing these different reporting purposes while presenting aid results according to the SDGs remains a challenge (Zwart 2017).

China, so far, has not participated in international fora for discussing results or evaluations as a donor country. As a donor, China offers little transparency regarding self-reported information on foreign aid, and information is not disaggregated on a country or project basis. In past years though, China has made significant moves towards a more systematic and open approach 
to reporting development results. First, the publication of white papers has provided more information, and now parts of China's aid portfolio are systematically monitored and evaluated using developmental criteria (Zhou 2016). Second, Chinese researchers are involved in numerous projects documenting the effects of aggregate Chinese aid and aid projects, with an increasing level of support from the Chinese government (Vazquez et al. 2016). Lastly, China has presented a detailed plan for implementing the SDGs and reported on progress towards achieving the SDGs, stating that

\begin{abstract}
China has pressed ahead with international cooperation under the Belt and Road Initiative, implemented a series of major result-oriented measures for international cooperation and stepped up assistance to other developing countries, particularly the LDCs [least-developed countries], making important contributions to regional and global implementation of the 2030 Agenda. (China Ministry of Foreign Affairs [MOFA] 2017, p. 73)
\end{abstract}

This analysis indicates that the development results idea (similar to mutual benefit) has the potential to be strategically used by policy entrepreneurs to foster convergence. The idea is polysemic, as it covers multiple dimensions and is understood differently across the various stakeholders. The valence of development results has traditionally been positive, and results reporting triggers high-intensity reactions. Next, development results have been legitimised by OECD-DAC donors and China across different policy documents. Nevertheless, policy entrepreneurs have not used development results as a coalition magnet so far to bring China, other South-South cooperation providers, developing countries, and OECD-DAC donors together.

\title{
10.4.3 2030 Agenda
}

The 2030 Agenda for Sustainable Development was agreed at the 2015 UN summit in New York and lays out a normative vision for global sustainable development (United Nations General Assembly 2015). It includes 17 goals across many different development dimensions and was carefully negotiated over several years and deliberated among all UN member states and other stakeholders. Thus, the 2030 Agenda is a highly valent and polysemic idea. It is valent because it is universally endorsed across the world and aspires to promote human development while safeguarding the planet. The idea of the 2030 Agenda is polysemic because no country is mandated to adopt each goal, but rather free to prioritise and implement certain parts of the agenda. Likewise, different actors are permitted to apply their own understandings of how the agenda should be achieved.

The legitimacy of the 2030 Agenda idea is unrivalled in development cooperation because it has been agreed by the UN, which has universal membership and is regarded as the most legitimate international organisation. Initially, the negotiation positions of China and OECD-DAC countries seemed to be quite 
far apart. In particular, there was the historical persistence of a North-South divide in the UN, often pinning OECD countries against the G77 and China, leading to gridlock across many areas of international cooperation (Fues and Ye 2014; Hale et al. 2013). Despite the adversarial starting position, there has been a high degree of convergence in positions between OECD countries and China, who have embraced the 2030 Agenda as a guiding framework for their development contributions, global policy discussions, and domestic policy-making.

China has actively engaged in the 2030 Agenda deliberations as a member of the Open Working Group-the official negotiation platform-and by publishing a position paper on the agenda (Fues and Ye 2014). Since 2015, China has introduced a National Plan on Implementation of the 2030 Agenda for Sustainable Development (China MOFA 2016) and published a "Progress Report on Implementation of the 2030 Agenda for Sustainable Development" (China MOFA 2017). Key Chinese planning documents such as the "Communique of the Fifth Plenary Meeting of the 18th Central Committee of the Chinese Communist Party" and the 13th Five-Year Plan reference the 2030 Agenda and tie it to domestic development strategies ( $\mathrm{Li}$ and Zhou 2016, p. 67). OECD countries have similarly embraced the 2030 Agenda in their foreign and domestic policies, although to varying degrees (OECD 2016).

The vital area for potential convergence is the notion of "universality", meaning that the development goals do not just apply to developing countries but that all countries, including OECD countries, need to apply the goals to their domestic development. Next, the 2030 Agenda has contributed towards joining the policy communities around "sustainable development" with the policy communities around "human development", as they had been separated within the UN and bureaucratic structures internationally (Bexell and Jönsson 2017). Another area of strong convergence has been the combination of goals, instruments, and review frameworks in the 2030 Agenda, expressed in the Addis Ababa Action Agenda on financing for development, the SDGs, and the follow-up and review mechanisms. Finally, China and OECD countries have jointly embraced the 2030 Agenda across various international fora, such as the G20 (Dongxiao et al. 2017; Li and Zhou 2016).

In terms of challenges and nuanced divergence, the issues of responsibility and burden-sharing stand out (Bexell and Jönsson 2017). These discussions can be summarised under the label of common but differentiated responsibilities (CBDR), which stems from the 1992 Rio Declaration on Environment and Development. The CBDR principle, however, has been slow to change into an updated understanding of differentiated forms of responsibilities (Dongxiao et al. 2017). More recently, however, emerging economies such as China have started applying the "intended nationally determined contributions" principle-introduced in the context of the Paris Agreement-to the 2030 Agenda. Based on "self-differentiation" (Mbeva and Pauw 2016), China proclaims self-determined contributions for achieving the 2030 Agenda in a bottom-up way. But critically, China still views itself as "the world's largest 
developing country" (Chin 2012; China MOFA 2016) and a "responsible major developing country" (China MOFA 2017). China, therefore, holds two potentially conflicting identities, being a developing country and a main global economic power at the same time.

Compared to mutual benefit and development results, the 2030 Agenda possesses the most significant potential of becoming a coalition magnet idea, given its polysemic character and strong positive valence. Besides, the 2030 Agenda has unmatched global legitimacy as a new sustainable development paradigm that has been universally endorsed by all UN member states. Despite these favourable conditions, policy entrepreneurs again struggled in using the 2030 Agenda to foster greater convergence between OECD countries and China, especially concerning the burden-sharing discussion.

\subsection{Contextualising Mutual Benefit, Development Results, ANd the 2030 Agenda in a Changing Global Development Landscape}

Comparing the ideas, it can be observed that each idea has a strong potential to become a coalition magnet idea, as each idea is polysemic and valent, and has been legitimised through various policy documents from OECD countries as well as from China. Yet, none of the ideas has been strategically used by policy entrepreneurs to foster convergence and consensus between OECD countries and China. As a next step, we contextualise our findings in the current landscape of global development discussions and explore the challenges that prevent policy entrepreneurs from fostering convergence generally as well as individually for each of the three ideas. Based on this analysis, we explore tentative steps that policy entrepreneurs could take to foster convergence for each of the three coalition magnet ideas.

In terms of challenges that prevent convergence around coalition magnet ideas, one key global trend has been the rise of identity-based populist and nationalist political movements in OECD countries (Luce 2017; Schmidt 2017) as well as in China (Johnston 2017). Gills (2017, p. 157) states that populist political currents have been making "a 'nationalist' appeal to citizens, and rejecting alternative cosmopolitan responses to the tensions generated by an increasingly globalized world". Cosmopolitan ideas on greater multilateral cooperation, such as mutual benefit, development results, and the 2030 Agenda, are therefore facing a generally unfavourable policy environment and are likely to encounter strong political opposition. Policy entrepreneurs, therefore, need to use their political power and rhetorical skills in politically smart ways (Béland and Cox 2016) to bridge the divide between nationalistic populism and cosmopolitan ideas of multilateralism.

Based on discursive institutionalism, this gap in multilateralism is closely linked to the divide between what Schmidt (2008) calls the coordinative and the communicative spheres of discourse. In the coordinative sphere, experts 
conduct policy discussions among themselves, whereas the communicative sphere involves the general public (Schmidt 2008). ${ }^{4}$ Each sphere requires distinctive discursive strategies (speaker, message, audience) to be successful in terms of achieving political change (Schmidt 2011). One key problem, however, has been that experts in the coordinative sphere have not sufficiently interacted with those in the communicative sphere, while the communicative sphere has been increasingly subject to the influence of technology and technological disruption (Schmidt 2017). As a result, public statements and practical policies keep diverging, as politicians make policy announcements that their administrations cannot deliver.

The main strategy for countering this trend is finding ways of coupling the coordinative and communicative spheres of discourse. Policy entrepreneurs need to disseminate their ideas across the coordinative policy sphere and the communicative politics sphere with tailored strategies to create new policy coalitions in national and international settings that may cut across political cleavages. We explore the concept of coupling the coordinative and communicative spheres of discourse by applying it to OECD countries and China for each of the three potential coalition magnet ideas. Therefore, we first reflect on the specific challenges to greater convergence for each idea and then sketch potential ways of bridging these challenges by coupling coordinative and communicative spheres of discourse.

For the potential coalition magnet idea of mutual benefit, two main obstacles prevent greater convergence. First, the strong emphasis on the commercial interests of OECD-DAC donors and China risks co-opting a developmental agenda for private gains. Already authors are warning that the main beneficiaries of mutual benefit-oriented aid in OECD-DAC countries are business elites and consultants (Mawdsley et al. 2016). Second, power relations in development cooperation are still largely skewed towards the aid provider, and the agency and voice of recipients are under threat. Previous efforts of OECDDAC donors to self-discipline, for example through the Paris Declaration on Aid Effectiveness, have failed and lost their political support. An attempt by OECD-DAC donors to extend the ODA definition towards total official support for sustainable development in a non-inclusive and non-transparent process was perceived as an attempt to shirk existing donor commitments (Besharati 2017).

Going forward, policy entrepreneurs face the challenge of fostering more nuanced and transparent dialogue on the balance of mutual benefit, where the main problem is not the existence of national interests but their concealment. Keijzer and Lundsgaarde (2017) propose extending the monitoring and evaluation toolbox of ODA to better track benefits outside of the recipient country. Such a step would improve transparency and allow for a more honest dialogue on foreign aid. Chinese foreign aid already systematically monitors mutual benefit in select projects, although these evaluations have not yet been published (Zhou 2016). Hence, China could move towards a 
more transparent discussion of how benefits are distributed in its cooperation, for instance by making internal tendering processes more transparent and open for competition. Although the transparent evaluation of mutual benefit is a long-term objective for policy entrepreneurs, a more immediate step could be a discussion on global public goods and enlightened self-interest. Using the coalition magnet idea of mutual benefit in this way could foster greater convergence between OECD-DAC donors and China and help to couple the coordinative and communicative spheres of discourse between the international and national levels.

For the potential coalition magnet idea of development results, the main challenge is that OECD-DAC donors and China are falling behind on established metrics of aid effectiveness. For example, the share of country programmable aid ${ }^{5}$ in bilateral ODA and the amount of ODA to LDCs $^{6}$ have declined in recent years (OECD 2017). A 2016 survey of 81 developing countries showed that only about half of all aid was spent through country systems (OECD and United Nations Development Programme 2016). These trends come at the expense of recipient countries. In the same way, developing countries that partner with China and its partners continue to have little insight and influence on the details of Chinese aid allocation and results reporting. Although China remains actively engaged with other providers of SouthSouth cooperation to jointly develop own reporting standards for development results, this process has been moving slowly.

Going forward, the SDGs provide sufficient room for policy entrepreneurs to foster the convergence of DAC donors and China in terms of reporting development results and harmonising monitoring and evaluation approaches. DAC donors have to achieve greater coherence and transparency in differentiating tiers of results (development results, development cooperation results, and performance) as well as purposes of results reporting (accountability, communication, direction, and learning) while upholding established aid effectiveness standards. China could increase its engagement for further defining South-South cooperation principles and standards while continuing its move towards more transparent and disaggregated reporting on its foreign aid. Moving into these directions again would be a way for OECD donors and China to better bridge the growing divide between the coordinative and communicative spheres of discourse, domestically as well as internationally. Yanguas (2018) suggests that there is a need for a new "moral vision" (Lumsdaine 1993) for aid that is based on "humane internationalism" through a better understanding and acknowledgement of the politics of aid.

For the potential coalition magnet idea of the 2030 Agenda, there is already a broad corridor of convergence. Yet, policy entrepreneurs face the challenge of working across global, regional, and national levels in coordinated ways, constantly reframing the idea of the 2030 Agenda according to these contexts and in ways that enable engagement and awareness among the broader public. This challenge of cultivating collective action across multiple sectors and scales is interconnected with the challenges of making difficult trade-offs across SDG 
goals and finding ways to hold societal actors accountable for their influence on the SDGs (Bowen et al. 2017). On top of addressing these interconnected governance challenges, policy entrepreneurs are confronted to link the coordinative sphere of discourse of policy construction with the communicative sphere of discourse of deliberation, contestation, and legitimisation (Schmidt 2017).

Going forward, there are many cases where policy entrepreneurs can use the coalition magnet idea of the 2030 Agenda to achieve political change and foster multilateral cooperation. China's SDG report already states that

China has strengthened economic dialogue and policy coordination with major economies including the US [United States], the EU [European Union], the UK [United Kingdom], France, Germany, India, Japan and Russia with a view to facilitating steady growth of the world economy and improving the development environment for developing countries. (China MOFA 2017, p. 76)

These efforts could be strengthened in line with "reciprocal peer-learning" (Mahn 2017; Pisano and Berger 2016), a learning process among equals. To achieve this goal, policy entrepreneurs have to build upon outreach activities started during the SDG negotiations and mobilise support around a continued global public conversation on the 2030 Agenda.

Overall, we have shown that each idea-mutual benefit, development results, and the 2030 Agenda-faces slightly different challenges in terms of coupling the coordinative and communicative spheres of discourse in addition to the increasing level of divergence between national-level politics and multilateralism. However, we also have demonstrated that each idea is already well anchored on the global and national levels, and if they are used strategically by policy entrepreneurs, they could link international norms to domestic processes of political and social change. Policy entrepreneurs, whether they are political leaders or social activists, need to be grounded in a deep understanding of the domestic context of each country - where they want to achieve political outcomes-to couple the coordinative and communicative spheres of discourse.

\subsection{Conclusion}

We have shown that the concept of coalition magnet ideas is a useful framework for analysing the challenges of international development cooperation, particularly the positions of the OECD donors and China that are seemingly at odds. We have applied the framework to three ideas-mutual benefit, development results, and the 2030 Agenda - and have analysed how each idea could be strategically employed by policy entrepreneurs to foster convergence and political change. Furthermore, we have briefly outlined how policy entrepreneurs can be politically smart in fostering convergence in the current global context of development cooperation, linking the domestic and global levels of policy-making. 
Based on our assessment of the three coalition magnet ideas, we draw the following conclusions about the role of ideas in fostering convergence among diverging policy preferences. First, coalition magnet ideas have the potential to bring DAC members and China together around policy prescriptions that fall into a broad corridor of national and international epistemic communities around respective coalition magnet ideas. For mutual benefit, we highlighted global public goods; for development results, we stressed nuanced results reporting; and for the 2030 Agenda, we identified reciprocal learning. Second, we sketched out how coalition magnet ideas can be effective tools for achieving policy change, even in a global environment that is characterised by nationalist tendencies. The key for policy entrepreneurs is to couple policy and communicative discourse through individually targeted policy messages.

Finally, our chapter is only a first general application of the concept of coalition magnet ideas to development cooperation in OECD-DAC countries and China. We have not focused on any discussions "beyond aid" (Janus et al. 2015; Lin and Wang 2016) for instance, which see development cooperation in a larger context of multilateral engagement across many policy areas and communities, such as private-sector actors or trade and investment relations. Hence, further research on mapping coalition magnets across different policy areas and forms of international cooperation could be the next step.

Second, we have not unpacked the detailed processes of how ideas become coalition magnet ideas at the domestic and international levels, beyond the stage of agenda-setting towards implementing policies that lead to actual political change. In particular, it would be pertinent to analyse to what extent policy entrepreneurs from OECD countries and China are able to couple the communicative and coordinative spheres of discourse across domestic and international audiences and epistemic communities. Thus, causal process tracing (Bennett and Checkel 2014; Jacobs 2013) of coalition magnet ideas on the domestic level could be a way to deepen our understanding of how some ideas become influential, while others do not. Third, the examples in this analysis focused on governmental actors driving political change from the top. Additional research could also consider the role of non-governmental actors and social mobilisation around coalition magnet ideas.

\section{Notes}

1. We use the terms "OECD-DAC donors", "OECD donors", and "DAC donors" synonymously in this chapter to refer to the 30 countries that are members of the OECD-DAC and report their aid according to the official development assistance definition.

2. In addition to the definition of "discourse", based on discursive institutionalism, we understand "development discourse" according to Apthorpe and Des Gasper, who state that development discourse "as a field lacks clear boundaries, since development and development studies have none either, and further that the types of discourse in them are not all of one type" (Apthorpe and Gasper 2014, p. 168). In total, they differentiate between five different major uses of "development discourse", out of which "development policy discourse" and "discourse 
of leading international development donors" are closest to the interests of this analysis.

3. For a more detailed analysis of power, including ideational power, see Blyth (2016), Carstensen and Schmidt (2016), Parsons (2016), and Widmaier (2016).

4. Similarly, Kingdon (1984) speaks about policy entrepreneurs being able to couple three streams-problem, policy, and political-through advocacy and brokerage during windows of opportunity.

5. Country programmable aid tracks the proportion of bilateral aid over which recipients have or could have significant say; 21 out 30 DAC member countries reduced their volume of country programmable aid between 2010 and 2015 (OECD 2017).

6. Since 2011, bilateral ODA flows to LDCs have fallen; 19 out of 30 DAC members provided less ODA to LDCs in 2015 than in 2010.

\section{REFERENCES}

Ahluwalia, M. S., Summers, L., Velasco, A., Birdsall, C. N., \& Morris, S. (2016). Multilateral development banking for this century's development challenges. Washington, DC: Center for Global Development.

Alesina, A., \& Dollar, D. (2000). Who gives foreign aid to whom and why? Journal of Economic Growth, 5(1), 33-63.

Allison, G. (2017). Destined for war: Can America and China escape Thucydides's trap? Boston, MA: Houghton Mifflin Harcourt.

Anand, P. B. (2004). Financing the provision of global public goods. The World Economy, 27(2), 215-237.

Ang, Y. Y. (2016). How China escaped the poverty trap. London and Ithaca, NY: Cornell University Press.

Apthorpe, R., \& Gasper, D. (2014). Arguing development policy: Frames and discourses. London and New York, NY: Routledge.

Baum, W., \& Tolbert, S. (1985). Investing in development: Lessons of World Bank experience. Finance and Development, 22(4), 25.

Béland, D. (2005). Ideas and social policy: An institutionalist perspective. Social Policy \& Administration, 39(1), 1-18.

Béland, D., \& Cox, R. H. (2010). Ideas and politics in social science research. Oxford: Oxford University Press.

Béland, D., \& Cox, R. H. (2016). Ideas as coalition magnets: Coalition building, policy entrepreneurs, and power relations. Journal of European Public Policy, 23(3), $428-445$.

Bell, S. (2011). Do we really need a new "constructivist institutionalism" to explain institutional change? British Journal of Political Science, 41(4), 883-906.

Bennett, A., \& Checkel, J. T. (2014). Process tracing. Cambridge: Cambridge University Press.

Berthélemy, J. C. (2006). Bilateral donors' interest vs. recipients' development motives in aid allocation: Do all donors behave the same? Review of Development Economics, 10(2), 179-194.

Besharati, N. A. (2017). New development finance measure should be TOSSD out the window! (Policy Insights 45). Johannesburg: South African Institute of International Affairs. 
Bexell, M., \& Jönsson, K. (2017). Responsibility and the United Nations' sustainable development goals. Forum for Development Studies, 44(1), 13-29.

Bickerton, C. J., Hodson, D., \& Puetter, U. (2015). The new intergovernmentalism: European integration in the post-maastricht era. JCMS: Journal of Common Market Studies, 53(4), 703-722.

Blyth, M. (2016). The new ideas scholarship in the mirror of historical institutionalism: A case of old whines in new bottles? Journal of European Public Policy, 23(3), 464-471.

Bowen, K. J., Cradock-Henry, N. A., Koch, F., Patterson, J., Häyhä, T., Vogt, J., et al. (2017). Implementing the "Sustainable Development Goals": Towards addressing three key governance challenges-Collective action, trade-offs, and accountability. Current Opinion in Environmental Sustainability, 26, 90-96.

Bräutigam, D. (2011). Aid "with Chinese characteristics": Chinese foreign aid and development finance meet the OECD-DAC aid regime. Journal of International Development, 23(5), 752-764.

Callahan, W. A. (2013). China dreams: 20 visions of the future. Oxford: Oxford University Press.

Campbell, J. L. (2002). Ideas, politics, and public policy. Annual Review of Sociology, $28(1), 21-38$.

Carstensen, M. B., \& Schmidt, V. A. (2016). Power through, over and in ideas: Conceptualizing ideational power in discursive institutionalism. Journal of European Public Policy, 23(3), 318-337.

Cepparulo, A., \& Giuriato, L. (2016). Responses to global challenges: Trends in aid-financed global public goods. Development Policy Review, 34(4), 483-507.

Chen, X. (2017). Win-win cooperation: Formation, development and characteristics. http://www.ciis.org.cn/english/2017-11/17/content_40072596.htm.

Chin, G. T. (2012). China as a "net donor": Tracking dollars and sense. Cambridge Review of International Affairs, 25(4), 579-603.

Chin, G., Pearson, M. M., \& Yong, W. (2013). Introduction-IPE with China's characteristics. Review of International Political Economy, 20(6), 1145-1 164.

Chin, G., \& Quadir, F. (2012). Introduction: Rising states, rising donors and the global aid regime. Cambridge Review of International Affairs, 25(4), 493-506.

China MOFA. (2017). China's progress report on implementation of the 2030 Agenda for Sustainable Development. http://www.fmprc.gov.cn/web/ziliao_674904/zt_ 674979/dnzt_674981/qtzt/2030kcxfzyc_686343/P020170824650025885740. pdf.

China Ministry of Commerce. (2014). Regulations on China's foreign aid management (trial). http://www.mofcom.gov.cn/article/b/c/201411/201411007 99438.shtml. English: http://www.cn.undp.org/content/china/en/home/lib rary/south-south-cooperation/measures-for-the-administration-of-foreign-aid-. html.

China MOFA (China Ministry of Foreign Affairs). (2016). National plan on implementation of the 2030 Agenda for Sustainable Development. http://www.fmprc.gov. cn/mfa_eng/zxxx_662805/W020161014332600482185.pdf.

China State Council. (2011). China's foreign aid. http://english.gov.cn/archive/ white_paper/2014/09/09/content_281474986284620.htm.

China State Council. (2014). China's foreign aid. http://english.gov.cn/archive/ white_paper/2014/08/23/content_281474982986592.htm.

Chun, Z. (2017). The Belt and Road Initiative and global governance in transition. China Quarterly of International Strategic Studies, 3(2), 175-191. 
Collier, P. (2013). Aid as a catalyst for pioneer investment (WIDER Working Paper No. 2013/004). Helsinki: United Nations University World Institute for Development Economics Research.

Collier, P. (2016). The ethical foundations of aid: Two duties of rescue (BSG Working Paper 2016/016). Oxford: Blavatnik School of Government.

Ding, S. (2010). Analyzing rising power from the perspective of soft power: A new look at China's rise to the status quo power. Journal of Contemporary China, 19(64), 255-272.

Dongxiao, C., Esteves, P., Martinez, E., \& Scholz, I. (2017). Implementation of the 2030 Agenda by G20 members: How to address the transformative and integrated character of the SDGs by individual and collective action. http://www.g20-insights. org/policy_briefs/implementation-2030-agenda-g20-members-address-transform ative-integrated-character-sdgs-individual-collective-action/.

Dreher, A., Eichenauer, V. Z., \& Gehring, K. (2016). Geopolitics, aid, and growth: The impact of UN security council membership on the effectiveness of aid. The World Bank Economic Review, 32(2), 268-286.

Eyben, R., Guijt, I., Roche, C., \& Shutt, C. (2015). The politics of evidence and results in international development: Playing the game to change the rules. Rugby: Practical Action Publishing.

Feng, Y. (2016). Ideas as domestic factors in the formation of China's multilateralist foreign policies: Cases of WTO, ASEAN+ 3 and SCO (dissertation). Brussels: Université Libre de Bruxelles.

Fligstein, N., \& McAdam, D. (2012). A theory of fields. Oxford: Oxford University Press.

Fues, T., \& Ye, J. (2014). The United Nations post-2015 agenda for global development: Perspectives from China and Europe. Bonn: German Development Institute/Deutsches Institut für Entwicklungspolitik (DIE).

Gill, B., \& Huang, Y. (2006). Sources and limits of Chinese "soft power". Survival, $48(2), 17-36$.

Gills, B. (2017). The future of development from global crises to global convergence. Forum for Development Studies, 44(1), 155-161.

Gilpin, R. (1983). War and change in world politics. Cambridge: Cambridge University Press.

Grimm, S. (2014). China-Africa cooperation: Promises, practice and prospects. Journal of Contemporary China, 23(90), 993-1011.

Grimm, S., Rank, R., Schickerling, E., \& McDonald, M. (2011). Transparency of Chinese aid: An analysis of the published information on Chinese external financial flows. Stellenbosch: Centre for Chinese Studies.

Gulrajani, N. (2017). Bilateral donors and the age of the national interest: What prospects for challenge by development agencies? World Development, 96, 375-389.

Hackenesch, C. (2013). Aid donor meets strategic partner? The European Union's and China's relations with Ethiopia. Journal of Current Chinese Affairs, 42(1), 7-36.

Hale, T., Held, D., \& Young, K. (2013). Gridlock: Why global cooperation is failing when we need it most. Cambridge: Polity Press.

Hay, C. (2006a). Constructivist institutionalism. In S. A. Binder, R. A. W. Rhodes, \& B. A. Rockman (Eds.), The Oxford handbook of political institutions. Oxford: Oxford University Press. https://doi.org/10.1093/oxfordhb/9780199548460.003.0004.

Hay, C. (2006b). Political ontology. In R. E. Goodin \& C. Tilly (Eds.), The Oxford handbook of contextual political analysis (pp. 78-96). Oxford: Oxford University Press. 
Holzapfel, S. (2016). Boosting or hindering aid effectiveness? An assessment of systems for measuring donor agency results. Public Administration and Development, $36(1), 3-19$.

Hood, C. (1991). A public management for all seasons. Public Administration, 69(1), 3-19.

Howlett, M., Ramesh, M., \& Perl, A. (2009). Studying public policy: Policy cycles and policy subsystems (Vol. 3). Oxford: Oxford University Press.

Hulme, D. (2016). Should rich nations help the poor? Hoboken, NJ: Wiley.

Jacobs, A. M. (2013). Process-tracing the effects of ideas. In A. Bennett \& J. T. Checkel (Eds.), Process tracing: From metaphor to analytic tool (pp. 41-73). Cambridge: Cambridge University Press.

Janus, H., \& Klingebiel, S. (2014). Results-based aid: Potential and limits of an innovative modality in development cooperation. International Development Policy/Revue internationale de politique de développement, 5.2. https://journals.ope nedition.org/poldev/1746.

Janus, H., Klingebiel, S., \& Paulo, S. (2015). Beyond aid: A conceptual perspective on the transformation of development cooperation. Journal of International Development, 27(2), 155-169.

Jessop, B. (2001). Institutional re(turns) and the strategic-relational approach. Environment and Planning A, 33(7), 1213-1235.

Johnston, A. I. (2017). Is Chinese nationalism rising? Evidence from Beijing. International Security, 41(3), 7-43.

Johnston, L., \& Rudyak, M. (2017). China's “innovative and pragmatic” foreign aid: Shaped by and now shaping globalisation. In L. Song, R. Garnaut, C. Fang, \& L. Johnston (Eds.), China's new sources of economic growth: Vol. 2: Human capital, innovation and technological change (pp. 431-452). Acton: Australian National University Press.

Kaul, I., Grunberg, I., \& Stern, M. A. (1999). Global public goods: Concepts, policies and strategies. In I. Kaul \& I. Grunberg (Eds.), Global public goods: International cooperation in the 21st century (pp. 450-508). Oxford and New York, NY: Oxford University Press.

Kearn, D. W., Jr. (2008). A hard case for soft power: China's rise and security in East Asia. Journal of Asian Politics and History, 3(5), 1-26.

Keijzer, N., \& Lundsgaarde, E. (2017). When unintended effects become intended: Implications of "mutual benefit" discourses for development studies and evaluation practices (Working Paper). Nijmegen: Ministry of Foreign Affairs of the Netherlands, and Radboud University.

Kenny, C., Snyder, M., \& Patel, D. (2018). Measures of global public goods and international spillovers (Working Paper No. 474). Washington, DC: Center for Global Development.

Kingdon, J. W. (1984). Agendas, alternatives, and public policies (Vol. 45). Boston, MA: Little, Brown.

Kitano, N., \& Harada, Y. (2016). Estimating China's foreign aid 2001-2013. Journal of International Development, 28(7), 1050-1074.

Knoll, A., \& Sheriff, A. (2017). Making waves: Implications of the irregular migration and refugee situation on official development assistance spending and practices in Europe (EBA reports 2017:01). Stockholm: The Expert Group for Aid Studies. 
Kragelund, P. (2015). Towards convergence and cooperation in the global development finance regime: Closing Africa's policy space? Cambridge Review of International Affairs, 28(2), 246-262.

Laclau, E. (1996). Emancipation(s). London and New York, NY: Verso.

Lee, P. S. (2016). The rise of China and its contest for discursive power. Global Media and China, 1(1-2), 102-120.

Li, X. (2012). Agricultural development in China and Africa: A comparative analysis. London: Routledge.

Li, X., Banik, D., Tang, L., \& Wu, J. (2014). Difference or indifference: China's development assistance unpacked. IDS Bulletin, 45(4), 22-35.

Li, X., \& Carey, R. (2014). The BRICS and the international development system: Challenge and convergence? (IDS Evidence Report 58). Brighton: Institute of Development Studies.

Li, X., Gu, J., Leistner, S., \& Cabral, L. (2018). Perspectives on the global partnership for effective development cooperation. IDS Bulletin, 49(3), 145-166.

Li, X., \& Zhou, T. (2016). Achieving the sustainable development goals: The role for the G20 from China's perspective. China \& World Economy, 24(4), 55-72.

Lin, J. Y., \& Wang, Y. (2016). Going beyond aid: Development cooperation for structural transformation. Cambridge: Cambridge University Press.

Luce, E. (2017). The retreat of Western liberalism. New York, NY: Atlantic Monthly Press.

Lumsdaine, D. H. (1993). Moral vision in international politics: The foreign aid regime, 1949-1989. Princeton, NJ: Princeton University Press.

Mahn, T. C. (2017). Accountability for development cooperation under the 2030 Agenda (Discussion Paper 10/2017). Bonn: German Development Institute/Deutsches Institut für Entwicklungspolitik (DIE).

Mawdsley, E. (2017a). Development geography 1: Cooperation, competition and convergence between "North" and "South". Progress in Human Geography, 41(1), 108-117.

Mawdsley, E. (2017b). National interests and the paradox of foreign aid under austerity: Conservative governments and the domestic politics of international development since 2010. The Geographical Journal, 183(3), 223-232.

Mawdsley, E., Murray, W. E., Overton, J., Scheyvens, R., \& Banks, G. (2016). Exporting stimulus and "shared prosperity": Re-inventing foreign aid for a retroliberal era. Development Policy Review, 36(S1), O25-O43.

Mbeva, K., \& Pauw, W. (2016). Self-differentiation of countries' responsibilities (Discussion Paper 4/2016). Bonn: German Development Institute/Deutsches Institut für Entwicklungspolitik (DIE).

Mearsheimer, J. J. (2010). The gathering storm: China's challenge to US power in Asia. The Chinese Journal of International Politics, 3(4), 381-396.

Minogue, M., Polidano, C., \& Hulme, D. (1998). Beyond the new public management. Cheltenham: Edward Elgar.

Minoiu, C., \& Reddy, S. G. (2010). Development aid and economic growth: A positive long-run relation. The Quarterly Review of Economics and Finance, 50(1), 27-39.

Morriss, P. (2006). Steven Lukes on the concept of power. Political Studies Review, $4(2), 124-135$.

Murray, W. E., \& Overton, J. (2016). Retroliberalism and the new aid regime of the 2010s. Progress in Development Studies, 16(3), 244-260. 
Nordin, A. H., \& Weissmann, M. (2017). Will Trump make China great again? The Belt and Road Initiative and international order. International Affairs, 94(2), 231249.

Nye, J. S. (2004). Soft power: The means to success in world politics. New York, NY: Public Affairs.

OECD. (2016). Better policies for 2030: An OECD action plan on the sustainable development goals. http://www.oecd.org/dac/Better\%20Policies\%20for\%202 030.pdf.

OECD. (2017). Development co-operation report 2017: Data for development. Paris: OECD Publishing.

OECD (Organisation for Economic Co-operation and Development). (2005/2008). The Paris Declaration on Aid Effectiveness and the Accra Agenda for Action. https://www.oecd.org/dac/effectiveness/34428351.pdf.

OECD \& United Nations Development Programme. (2016). Making development co-operation more effective: 2016 progress report. Paris: OECD Publishing.

Parsons, C. (2016). Ideas and power: Four intersections and how to show them. Journal of European Public Policy, 23(3), 446-463.

Paul, E. (2015). Performance-based aid: Why it will probably not meet its promises. Development Policy Review, 33(3), 313-323.

Pisano, U., \& Berger, G. (2016). Exploring peer learning to support the implementation of the 2030 Agenda for SD (Quarterly Report 40). Vienna: European Sustainable Development Network.

Qian, Y. (2017). How reform worked in China: The transition from plan to market. Cambridge, MA: MIT Press.

Radaelli, C. M. (2006). Europeanization: Solution or problem? In M. Cini \& A. K. Bourne (Eds.), Palgrave advances in European Union studies (pp. 56-76). New York, NY: Springer.

Rawnsley, G. D. (2016). Reflections of a soft power agnostic. In X. Zhang, H. Wasserman, \& W. Mano (Eds.), China's media and soft power in Africa (pp. 19-31). New York, NY: Springer.

Reilly, J. (2012). A norm-taker or a norm-maker? Chinese aid in Southeast Asia. Journal of Contemporary China, 21(73), 71-91.

Risse-Kappen, T. (1994). Ideas do not float freely: Transnational coalitions, domestic structures, and the end of the Cold War. International Organization, 48(2), 185214.

Rowlands, D. (2012). Individual BRICS or a collective bloc? Convergence and divergence amongst "emerging donor" nations. Cambridge Review of International Affairs, 25(4), 629-649.

Schmidt, V. A. (2008). Discursive institutionalism: The explanatory power of ideas and discourse. Annual Review of Political Science, 11, 303-326.

Schmidt, V. A. (2010). Taking ideas and discourse seriously: Explaining change through discursive institutionalism as the fourth "new institutionalism". European Political Science Review, 2(01), 1-25.

Schmidt, V. A. (2011). Speaking of change: Why discourse is key to the dynamics of policy transformation. Critical Policy Studies, 5(2), 106-126.

Schmidt, V. A. (2017). Britain-out and Trump-in: A discursive institutionalist analysis of the British referendum on the EU and the US presidential election. Review of International Political Economy, 24(2), 248-269. 
Shambaugh, D. (2015). China's soft-power push: The search for respect. Foreign Affairs, 94(4), 99-107.

Shi-Kupfer, K., Ohlberg, M., Lang, S., \& Lang, B. (2017). Ideas and ideologies competing for China's political future (MERICS Paper on China No. 5). Berlin: Mercator Institute for China Studies.

Sidiropoulos, E., Pineda, J. A. P., Chaturvedi, S., \& Fues, T. (2015). Institutional architecture and development: Responses from emerging powers. Johannesburg: South African Institute of International Affairs.

Sørensen, C. T. (2015). The significance of Xi Jinping's “Chinese Dream” for Chinese foreign policy: From "Tao Guang Yang Hui" to "Fen Fa You Wei”. Journal of China and International Relations, 3(1), 53-73.

Strange, A. M., Dreher, A., Fuchs, A., Parks, B., \& Tierney, M. J. (2017). Tracking underreported financial flows: China's development finance and the aid-conflict nexus revisited. Journal of Conflict Resolution, 61(5), 935-963.

Turner, M., Hulme, D., \& McCourt, W. (2015). Governance, management and development: Making the state work. Basingstoke: Palgrave Macmillan.

United Nations General Assembly. (2009). The Nairobi outcome document of the HighLevel United Nations Conference on South-South Cooperation. https://digitallibrary. un.org/record/673444.

United Nations General Assembly. (2015). Transforming our world: The 2030 Agenda for Sustainable Development. https://www.unfpa.org/sites/default/files/resourcepdf/Resolution_A_RES_70_1_EN.pdf.

United Nations General Assembly. (2019). Buenos Aires outcome document of the Second High-Level United Nations Conference on South-South Cooperation. https:// digitallibrary.un.org/record/3801900?ln=enbly.

Varrall, M. (2013). Chinese views on China's role in international development assistance. Pacific Affairs, 86(2), 233-255.

Vazquez, K., Xiaojin, M., \& Yao, S. (2016). Mix and match? How countries deliver development cooperation and lessons for China. United Nations Development Programme and the Chinese Academy of International Trade and Economic Cooperation. http://dspace.jgu.edu.in:8080/jspui/bitstream/10739/1003/1/UNDPCH-SSC-\%20Mix\%20and\%20Match\%20How\%20Countries\%20Deliver\%20Develop ment $\% 20$ Cooperation $\% 20$ and $\% 20$ Lessons $\% 20$ for $\% 20$ China.pdf.

Wang, H. (2014). From “taoguang yanghui” to "yousuo zuowei”: China's engagement in financial minilateralism (CIGI Papers No. 52). Waterloo: Centre for International Governance Innovation.

Wang, Q. K., \& Blyth, M. (2013). Constructivism and the study of international political economy in China. Review of International Political Economy, 20(6), 12761299.

Widmaier, W. (2016). The power of economic ideas-Through, over and in-Political time: The construction, conversion and crisis of the neoliberal order in the US and UK. Journal of European Public Policy, 23(3), 338-356.

Woods, N. (2008). Whose aid? Whose influence? China, emerging donors and the silent revolution in development assistance. International Affairs, 84(6), 12051221.

Xi, J. (2017, October 18). Report at 19th Communist Party of China national congress. China Daily. http://www.chinadaily.com.cn/china/19thcpcnationalcon gress/2017-11/04/content_34115212.htm. 
Yang, J. (2018). The 19th CPC national congress and China's major country diplomacy in the new era. QiuShi Journal, 10(34). http://english.qstheory.cn/201802/11/c_1122395899.htm.

Yanguas, P. (2017). The role and responsibility of foreign aid in recipient political settlements. Journal of International Development, 29(2), 211-228.

Yanguas, P. (2018). Why we lie about aid: Development and the messy politics of change. London: Zed Books.

Younis, M. (2013). Rising powers in international development-Report from the series of events held by IDS and partners in Johannesburg preceding the 5th BRICS summit in March 2013 (Evidence Report 24). https://opendocs.ids.ac.uk/opendocs/bitstr eam/handle/123456789/2948/ER24\%20Final\%20Online.pdf?sequence=1.

Zhang, Y., Gu, J., \& Chen, Y. (2015). Rising powers in international developmentChina's engagement in international development cooperation: The state of the debate (Evidence Report 116). https://opendocs.ids.ac.uk/opendocs/bitstream/handle/ 123456789/5838/ER116_ChinasEngagementinInternationalDevelopmentCooper ationTheStateoftheDebate.pdf? sequence $=1$ \&isAllowed $=y$.

Zhou, E. (1964). The Chinese government's eight principles for economic aid and technical assistance to other countries. http://digitalarchive.wilsoncenter.org/document/ 121560.

Zhou, T. (2016). Evaluating South-South development cooperation: China's approach and trends. Seoul: Korea Development Institute and The Asia Foundation.

Zhou, T., \& Zhang, H. (2018). China's Belt and Road Initiative: An opportunity to re-energize South-South cooperation. China Quarterly of International Strategic Studies, 4(4), 559-576.

Zwart, R. (2017). Strengthening the results chain: Synthesis of case studies of resultsbased management by providers (OECD Development Policy Papers, No. 7). Paris: OECD Publishing.

Open Access This chapter is licensed under the terms of the Creative Commons Attribution 4.0 International License (http://creativecommons.org/licenses/by/4.0/), which permits use, sharing, adaptation, distribution and reproduction in any medium or format, as long as you give appropriate credit to the original author(s) and the source, provide a link to the Creative Commons license and indicate if changes were made.

The images or other third party material in this chapter are included in the chapter's Creative Commons license, unless indicated otherwise in a credit line to the material. If material is not included in the chapter's Creative Commons license and your intended use is not permitted by statutory regulation or exceeds the permitted use, you will need to obtain permission directly from the copyright holder.

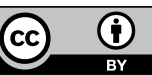

